\title{
Disempowering Forces and Disillusioned Selves: A Constructivist Grounded Theory Analysis of Demotivation among French Student Learners of English
}

\author{
Rowland Hill' ${ }^{1}$, Véronique Pottier ${ }^{2}$ \\ ${ }^{1}$ Interlink, 2 rue Gaston Doumergue, 85180 Le Château d'Olonne, France \\ ${ }^{2}$ Lycée professionnel Eric Tabarly, 3, rue Eric Tabarly, 85430 Olonne sur Mer, France
}

Corresponding Author: Rowland Hill, E-mail: hill@interlink-services.com

\section{ARTICLE INFO}

Article history

Received: February 24, 2018

Accepted: April 27, 2018

Published: September 01, 2018

Volume: 7 Issue: 5

Advance access: July 2018

Conflicts of interest: None

Funding: None

\begin{abstract}
France sits steadfastly at the bottom of EU rankings for English proficiency, and yet French learners have an equivalent access to educational resources and teacher competence. It is a curious phenomenon which points to pupil demotivation during second language (L2) learning at school as a likely cause. The dominant model in L2 motivation - Dörnyei's Motivational Self System - with its symbiosis of the ought self, the ideal self and the quality of the learning environment, has had its usefulness verified in other countries, but lacks sufficient flexibility to explain L2 demotivation in France. As a departure from the existing corpus of quantitative research on L2 motivation, this research uses Charmaz' constructivist grounded theory approach to delve into the L2 learning experiences of twelve French students at a qualitative level. The originality of this approach is that the researcher must relinquish preconceived ideas, enter the constructed world of the participant and make conceptual sense of the data produced from the shared construction. The resulting force field/self-discrepancy model indicates that pupils are prevented from reaching language proficiency by disempowering forces, for example, limited contact with English speakers, and that this is compounded by negative emotions arising from discrepancies between the learner's actual, ought and ideal selves. To address the complexity of this model, French schools should begin by empowering students to set targets towards a realistic English-speaking ideal self. Otherwise, there is a danger that the ideal L2 self becomes another source of disillusionment and hence another disempowering force.
\end{abstract}

Key words: Demotivation, Second Language Learning, Constructivist, Dis/Empowering Force, Self-discrepancy

\section{INTRODUCTION}

France is ranked $24^{\text {th }}$ out of the 24 EU countries listed in the 2015 English Proficiency Index (Lewandowski, 2015). According to English First (2015), who publish the English Proficiency Index (EPI), the situation has stagnated since 2007. Indeed, it is young French adults who are continuing to lower the overall level of proficiency, putting France on a par with Mexico and China. However, these 'low' band French learners are taught by well-qualified teachers and are allotted as many English lessons as their 'very high' proficiency Nordic counterparts. One plausible explanation is the lack of exposure to English in everyday life, but Austria is ranked $10^{\text {th }}$, and like France, it also dubs English-speaking films and series (English First, 2015). This leaves demotivation during the second language (L2) learning experience at school as an alternative, credible explanation.

Demotivation in second language learning has been defined by Dörnyei and Ushioda (2011) as the negative influences that affect a student's motivation during the learning process. Dörnyei's Motivational Self System is currently the dominant L2 model. It is based on the interaction of an ideal self (self-perception of an imagined L2 self), an ought self (one's acceptance of the attributes required to attain the ideal self) and the quality of the immediate learning environment (Dörnyei, 2005). As the ideal self is invariably represented by the L2 speaking other, Dörnyei's model hinges on the level of contact a learner has with the L2 other's culture. However, the considerable gap between the French and Austrian EPI rankings does not sit neatly with the three components of the Self System. Theoretically, a French learner equipped with clear long-term goals and the means to reach these goals in a rich learning environment should have every chance of becoming proficient in English. This is not the case. Logic would therefore dictate that we move away from theory and attend to the voices of those who are actually in the process of learning English: the learners themselves.

The aim of this research is to have a direct conversation with French students about learning English at school. If at some point in their education they have become demotivated: 
(1) What has caused this demotivation? and (2) What are the emotional repercussions?. To answer these two key questions, a constructivist grounded theory approach is deemed appropriate because it allows socially constructed data to form the basis of the research rather than conventional thinking i.e. the participants remain the focal point at all times. The socially constructed data in this research derive from a series of semi-structured interviews with twelve students from a lycée professionnel (vocational school) in the west of France. The analysis of the interview data should contribute to a deeper conceptual understanding of the obstacles and emotions that cause learners to stumble on the path towards L2 proficiency.

\section{LITERATURE REVIEW}

\section{Demotivation in Psychology}

The act of running towards the train [...] has no instinctive element about it. It is purely the result of education, and is preceded by a consciousness of the purpose to be attained and a distinct mandate of the will. It is a 'voluntary act'. (James, 1890, p.13)

Motivation is therefore the deliberate pursuit of a specific goal. This pursuit requires knowledge, self-awareness and inner force. In addition, if the runner possesses a good level of fitness, he or she will expect to succeed, and if the runner aims to attend an important meeting, he or she will have the incentive to succeed. This builds on James' definition by introducing an expectancy x value equation (Tolman, 1938), which may explain why a runner with low expectancy and incentive may simply stop running towards the train.

To arrive on time, the runner must also have ample confidence to problem-solve and accomplish tasks by following a course of action: self-efficacy (Bandura, 1977). Otherwise, he or she will arrive late, and if this is the case, failure might be attributed to the internal/external loci of self-ability, effort, task difficulty and luck, and trigger feelings of shame (Weiner, 1985). The constant jostling between what the runner controls (intrinsic motivation) and what controls the runner (extrinsic motivation) may even lead to a sense of anxiety (Eccles \& Wigfield, 1985). We might also consider the runner's pressurised desire to compete with others (performance goals) rather than be challenged by the nature of the task itself (mastery goals) (Dweck, 1986), or we might be drawn to the runner's need for autonomy, competence and relatedness, which is his or her self-determination, to succeed (Deci \& Ryan, 1985). All in all, it seems that the simple act of running for a train may turn into a tortuous affair!

What we learn from the above predominant theories is that motivation and demotivation are presumably dichotomous: we experience positive/negative emotions as we succeed/fail to achieve goals. We also learn that no single theory is of sufficient scope to explain the complex interplay between biological, environmental, cognitive, behaviourist, humanistic and sociocultural factors.

\section{Demotivation in L2 Learning}

The dominant motivational theory in L2 learning, Dörnyei's Motivational Self System, is primarily based on the concept of possible selves: the ideal self and the ought self (Dörnyei, 2005). These selves must combine to spur us toward action: the learner sees him or herself as being a fluent speaker of English in the future and there are actions he or she ought to take to achieve this aim. The ideal self is also the English-speaking other, so the learner must have the opportunity to integrate the other's culture. The Motivational Self System therefore consists of intrinsic and extrinsic motivation. It also involves performance and mastery goals. Indeed, it appears to shadow existing theories from mainstream psychology.

The research on L2 learning has increasingly adopted the Motivational Self System as its guiding compass and has tended to concentrate on motivation rather than demotivation (see Kostoulas \& Mercer, 2016). The importance of preparing the ground for L2 learners seems to have taken precedence over protecting them from negative experiences, for instance, the latest addition to the model is mental imagery of the ideal self (Kim \& Kim, 2014), but imagining oneself capable of writing word-perfect emails may enfranchise visual learners, but disenfranchise auditory learners. Qualitative studies (Campbell \& Storch, 2011; Poupore, 2013; Waninge et al., 2014) indicate that a combination of factors, such as level of difficulty and emotional state, lead to fluctuating levels of motivation over time, whereas quantitative studies have concluded that educational materials and test scores (Sakai \& Kikuchi, 2009), or teaching methods and learning difficulty (Song \& Kim, 2017), are the most significant causes of demotivation. Research is steadily uncovering an ever-growing list of interrelated demotivational factors, but to date, the emotional ebb and flow of L2 demotivation, as well as the impact of one person's motivation on another's, do not appear to have been examined.

By relying on a prominent model as its bedrock there is a risk that L2 research may succumb to tunnel vision. The Motivational Self System is not falsifiable (see Popper, 1963) and will therefore require regular scrutiny. A second danger is that a dominant model may cause issues of researcher allegiance and conflicts of interest (Lieb et al., 2016). The allegiance effect pertains to the phenomenon whereby results consistently show a theory in a positive light because a researcher believes in the efficacy of that theory. The estimated export revenue for the UK's English Language Teaching sector was $£ 1.6$ billion in 2014 (ICEF Monitor, 2016). This may lead to a vested interest in promoting the virtues of a particular theory and its accompanying teaching methodology. A constructivist grounded theory approach should obviate this second danger and simultaneously challenge conventional L2 wisdom by prioritising data over existing theory.

\section{METHODOLOGY}

\section{Qualitative Approach}

The preferred analytical tool for this research is a constructivist grounded theory approach. The essence of grounded theory is that the researcher stays grounded in the data at all times. The data, rather than theory, lead the research.

We gather data, compare them, remain open to all possible theoretical understandings of the data, and develop 
tentative interpretations about these data through our codes and nascent categories. (Charmaz \& Henwood, 2007, p.241)

This approach is appropriate for the study because it views behaviour as implanted in a particular context, and it acknowledges the interaction between the researcher and the participants as they co-construct the data. These data are recorded as written text and the basic social processes, such as coming to terms with a new language, are identified. These basic social processes are then coded, or categorised, to reveal the themes that pervade the text. Charmaz (2014) recommends line-by-line coding followed by focused coding and theoretical coding, with constant memo-writing to help the researcher reflect on what is emerging from the data. She codes with the verb-noun 'ing' form, the gerund, to give a sense of action and purpose to what is happening in the interactions, hence encouraging the researcher to analyse from the participant's perspective. She also insists that the participants' language forms the basis of the codes: this is referred to as 'in vivo' coding.

\section{Ethical Approval}

The ethical approval for this research was granted by the ethics panel at Manchester Metropolitan University.

\section{Ethical Considerations}

A meeting was set up to ensure that the participants would understand the voluntary nature of their contribution and its potential value to the research. The participants were also informed that access to counselling support was available: returning to past experiences, especially negative experiences, may unearth unresolved feelings of anger and disappointment. Confidentiality, including anonymity, was guaranteed in order to protect the participants' right to privacy, except where interview discussion might indicate that a participant was at risk of harm or causing harm to others. To overcome the vulnerability associated with one-to-one interviews, the interview location was a convenient office on a busy corridor: the door was left slightly ajar to ensure privacy. Informed consent was gained prior to the interviews and the participants were debriefed at the end of each interview. The above considerations adhere to the British Psychological Society Code of Ethics and Conduct (2009).

\section{Design/Data Collection}

A semi-structured interview design was chosen because this is considered to be the most appropriate qualitative method for understanding people's experiences (Blandford, 2013). The five guiding interview questions functioned as both a topic guide and aide-memoir (Arthur \& Nazroo, 2003), and were devised to elicit information on the students' experiences of learning English at school: (1) How did you feel about English when you started learning it at school? What was your motivation like? (2) How do you find learning English now? What is your motivation like? (3) How do you feel when you are asked to say something in English? (4) How would the people around you describe your motivation to learn English? (5) If you had the chance to go back in time, how would you improve your English learning experience? All written and spoken text relating to the project was in French.

\section{Participants}

Twelve students on an HND-equivalent Brevet de Technicien Supérieur (BTS) Technical Sales sandwich course were recruited at a lycée professionnel (vocational school) in France. The students were aged between 18 and 21: ten were male; two female, which reflects the gender composition of the full-size BTS group (14:3). The advantage of interviewing BTS students is that they have attended different secondary schools (collège: 11-15; lycée: 16-18), hence broadening the scope of the research data, and their experiences are recent. Charmaz (2014) recommends gathering substantial data ('thick' data) to prevent superficial conceptual claims and offset the effects of contradictory accounts. Recruiting twelve participants enabled the collection of 25,000 words of 'thick' data.

\section{Procedures}

The students were interviewed individually for 15 to $20 \mathrm{~min}$ utes over a two week period. The content of the interviews was recorded onto a standalone wireless recording microphone. As recommended by Charmaz (2014), the interviews were as informal and conversational as possible. This was to build rapport, which Legard et al. (2003) highlight as being crucial in establishing trust. The twenty minute duration was determined by the amount of English lesson time available and by the observation from the BTS teacher that the students would be unlikely to volunteer for a longer period. After each set of four interviews, the data was converted into a simple mind map (see example in Figure 1) to compensate for the time constraints that prevented the recommended transcription/coding of interview data before proceeding to the next interview (Charmaz, 2015).

\section{Data Analysis}

The interview audio files were transferred to VLC Media Player, which offers a variable playback speed during transcription. Each password-protected recording was transcribed in French in an MS Word document containing a three-column table for coding in English and a space on the right hand side for memo-writing in English. To ensure anonymity, each participant is referred to as a letter of the alphabet chosen at random from the name of the school.

In the constructivist grounded theory approach the researcher begins by coding each line of the data at speed (line-by-line coding) in order to gain a sense of what is happening in the data - what are the inherent social processes? Comparable processes are combined to form focused codes, and in turn, these processes are combined to form theoretical codes. The theoretical codes are then grouped into logical conceptual categories whose interrelations are explained by a core category. In line 3 of the following excerpt (Figure 2), 


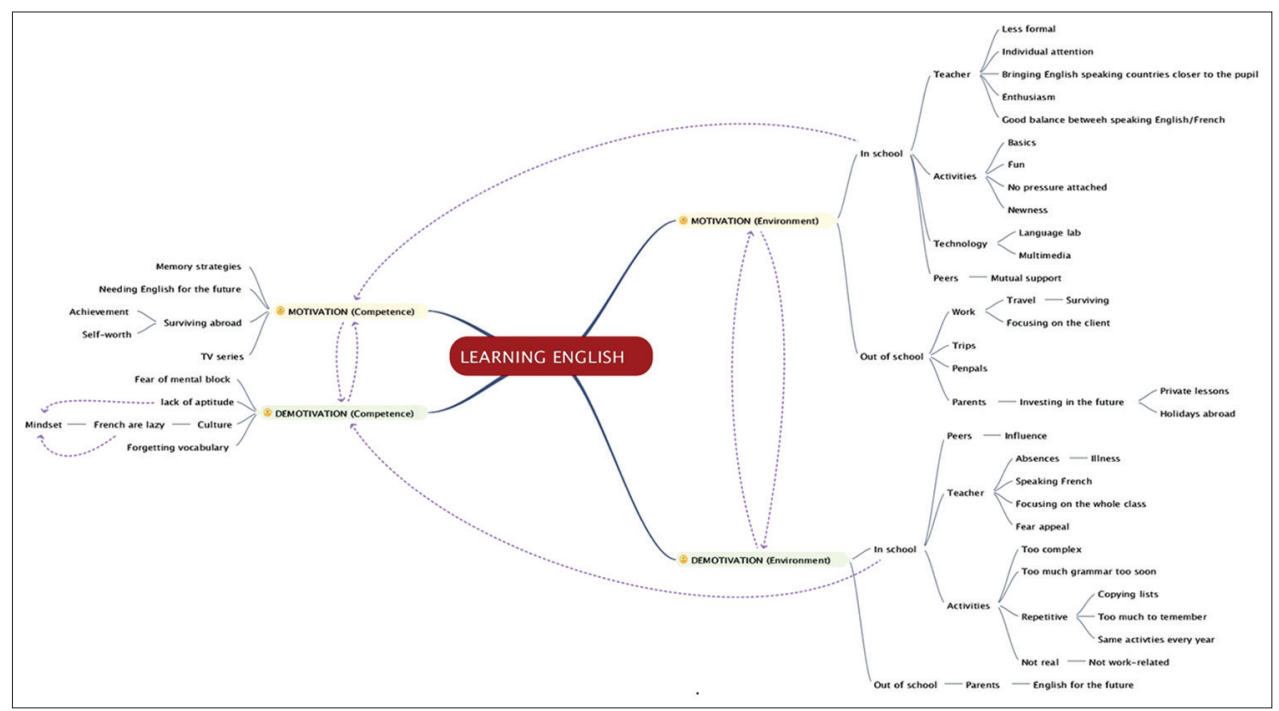

Figure 1. Mind map after the first four interviews

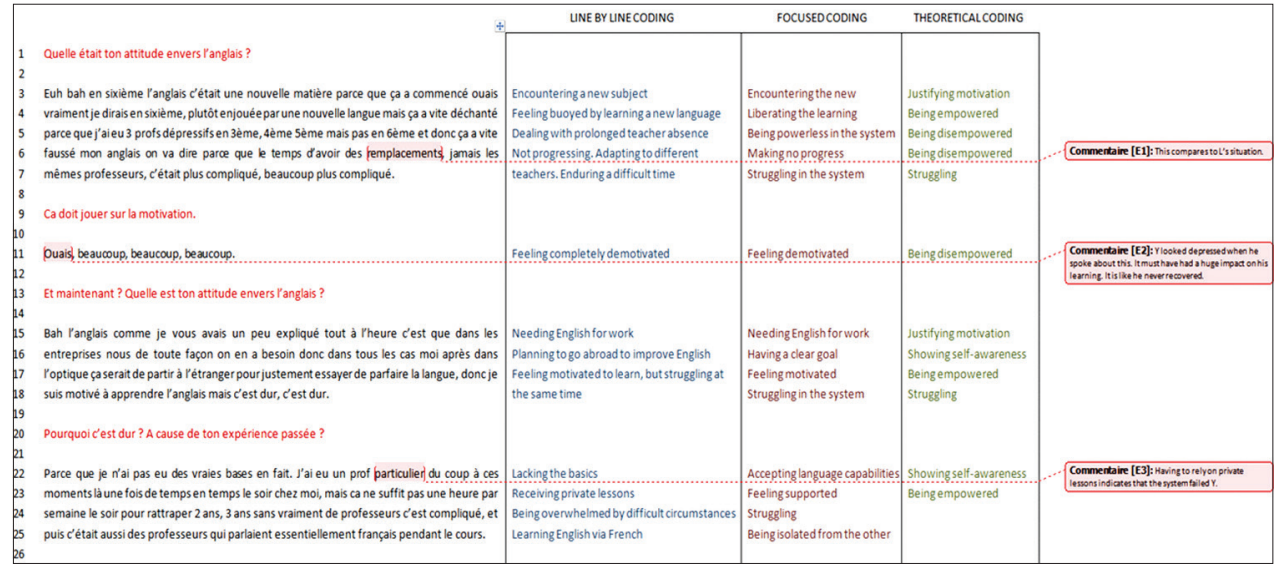

Figure 2. Excerpt from data analysis (participant $\mathrm{Y}$ )

Y talks about English being a new subject for him in Sixième (Year 7). The line-by-line code is 'encountering a new subject'; the focused code is 'encountering the new' and the theoretical code is 'justifying motivation'. The term 'new' traverses the first two codes before being conceptualised as a justification for Y's initial interest in learning English.

There are nine stages in the constructivist grounded theory approach (see Figure 3): each stage was constantly revisited throughout the research to ensure that the final conceptual model would be indelibly linked to the data. In practical terms, as each transcript was coded, earlier transcripts were checked for coding comparison and consistency. A number of concepts, such as fear appeal and mindset (see mind map above), became apparent during coding. These were recorded in memos and formed the basis for critical reflection.

\section{Evaluation of the Analysis}

The epistemological basis for this research is social construction, which embraces language as the essential component in our understanding of reality (Berge \& Luckmann, 1966). However, coding a French person's spoken text into English adds a layer to the process of knowledge construction i.e. the researcher's English construction of the researcher's French construction of the participant's French construction. The onus is therefore on the researcher to acknowledge the impact of increasing subjectivity on the data by harnessing the objective patterns of each language in order to optimise meaning. This search for equivalence at a word, grammatical and textual level forces the translator/researcher to scrutinise every meaning intention, and scrutiny is bolstered by the presence of doubt. Indeed, Charmaz (2017) advocates doubt during the interpretation of the data because doubt may generate theory through abductive reasoning (Locke et al., 2008).

In vivo coding may carry the interviewee's language through to the conceptualisation stage of the process, but it is not possible for all coding to be in vivo. A further analytical tool is required to study patterns in the text itself and to shackle the researcher's interpretation of the data. Lexical strings act as a cohesive resource, binding the disparate parts of a text through the identification of thematically-linked lexical items (Eggins, 2004), for instance, 'surviving' is both a theoretical code and a lexical theme. By noting the number of times a related lexical item appears in the text along with the number of students who have used it, we can gauge its importance in terms of both cohesion and coding. 
There is a certain confusion over Charmaz' use of the gerund. Often her coding examples are in the continuous verb form rather than the gerund, which is a verb-noun e.g., 'coaching' is a gerund in the sentence: 'Basketball coaching is important', whereas coaching is a present continuous verb form in 'I am coaching basketball'. The gerund denotes process, but there is a subtle difference between using 'basketball coaching' and 'coaching basketball' as codes. The latter is generally specific to a person; the former is more general. The present continuous verb form was preferred for this research.

\section{FINDINGS}

This section examines the findings of the constructivist grounded theory analysis, starting at a descriptive level and finishing with the creation of a core category (encapsulates the conceptual message of the findings) and the interpretation of this category.

\section{Descriptive}

The L2 learning process for the twelve participants is depicted descriptively in Figure 4 below: motivational and demotivational factors (represented by the focused codes) influence a student's level of motivation over time. It is also clear from the graph that there is a dichotomy between 'in school' and 'out of school' experiences. If we exclude such things as the initial newness of the language, the arrival of an inspirational teacher or lessons designed for specific purposes, the 'in school' experience tends to be demotivational whereas the 'out of school' experience of school trips, internships and holidays abroad tends to be motivational. When a student opts for the BTS sandwich course at 18, English usage may become continuous in and out of school.

What stands out most is the dramatic fall in motivation which occurs at some point before the end of Sixième (Year 7) when pupils are aged 11 to 12 . This applies to ten of the participants and is typified by the following statement:

My experience in primary school was good. It was my first before Sixième. But in Sixième, English lessons were compulsory. And that's when things got really bad. [E, 12-14]

At BTS level (aged 18 and over), the interest in English rises along with the motivation to become proficient. This reflects the usefulness of English for the professional context and for travelling.

It's not about having fun anymore. You need it for work. You reach an age when you just want to travel. At $20 \mathrm{ev}$ eryone wants to see the world, to discover. [L, 134-135]

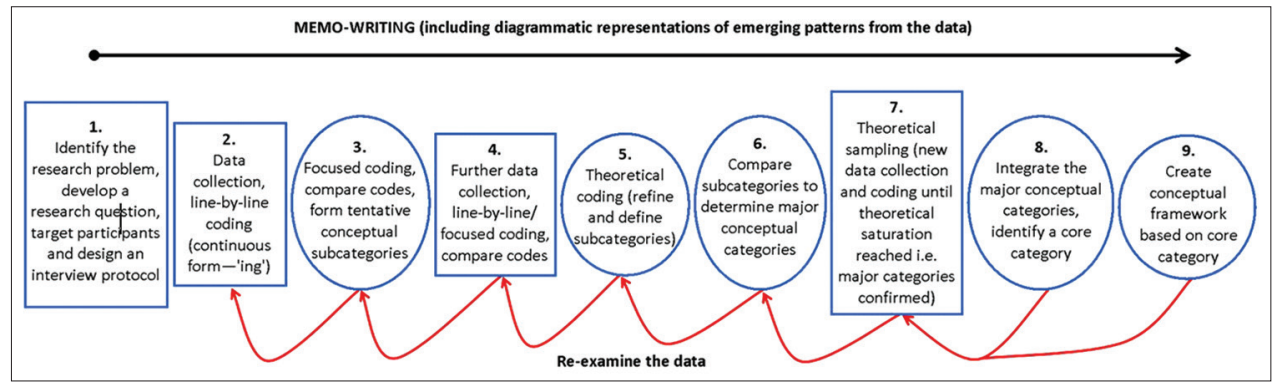

Figure 3. Constructivist grounded theory process

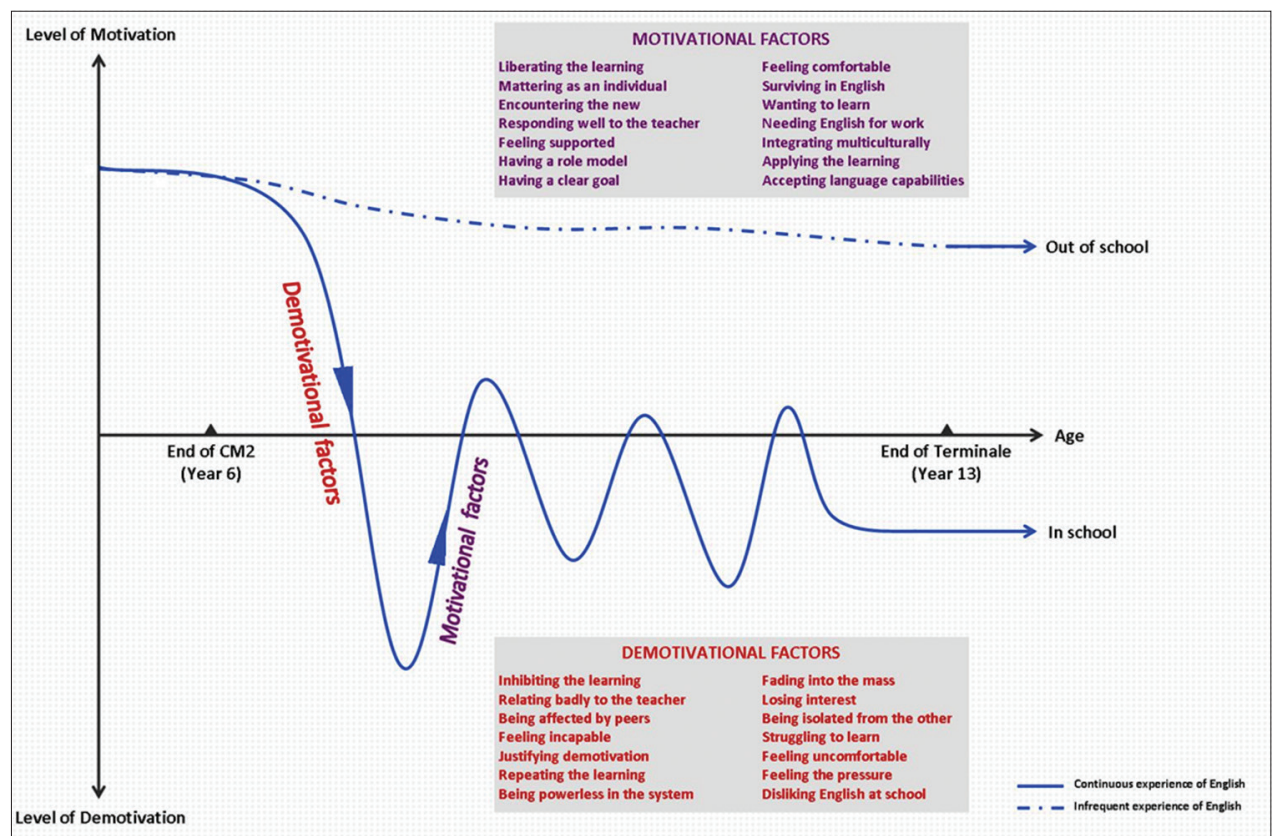

Figure 4. The process of learning English at school in France 
The above descriptive summary provides a thematic overview of the students' constructed reality based on the contents of the interviews. The next subsection identifies the conceptual categories that emerged after the completion of the line-by-line, focused and theoretical coding.

\section{Conceptual Categories}

The following six conceptual categories emerged at the theoretical coding stage:

1. Being empowered/Being disempowered

2. Surviving/Struggling

3. Feeling comfortable/Feeling uncomfortable

4. Showing self-awareness/Lacking self-awareness

5. Justifying motivation/Justifying demotivation

6. Integrating with the other/Being isolated from the other

The subsections below reflect on how the experiences of the students are embedded in the conceptual categories (the lexical strings for each category are in brackets):

\section{Category 1. Being empowered/Being disempowered (individual/mass, enjoyment, interest, obligation, disinterest, repetition, behaviour problems, pressure, lack of support, teacher disruption)}

This category contains the highest number of focused codes. Zimmerman (2000) defines empowerment as "a process in which efforts to exert control are central" (p.44). This implies that disempowerment is a process for which the possibility of exerting control is removed. Zimmerman goes on to suggest that the efforts we exert are to better achieve our goals and to improve our quality of life. The focused codes for the students give a clear sense of empowerment versus disempowerment, for example, liberating/inhibiting the learning, feeling supported/unsupported, gaining/losing interest and relating well/badly to the teacher. The students may even be empowered and disempowered in quick succession.

We had fun in CM1 (Year 5). We played games, like Sparrow Hawk (British Bulldog). We learned simple words and expressions. We did different topics. Everything changed in CM2 (Year 6). It was more formal. We sat on benches. We learned. We didn't have any choice. It was education for the masses. [L, 3-6]

$\mathrm{L}$ experiences a downward shift in emotion and control. Her use of the word 'masses' immediately conjures up the writings of Marx (1867/1887) where control remains firmly in the hands of the owners of the means of production who exploit the "homogeneous mass of human labour power" (p.29). This epitomises a factory model of education in which children are prepared for the realities of the industrial world (Watters, 2015). In contrast to L's dystopian views, A was empowered after receiving more individual attention within a smaller group: ...we were getting more help. There weren't so many of us, so it didn't feel like we were being treated like cattle. [A, 152]

Being disempowered is especially evident in the 'repeating the learning' code.

...I remember in Quatrième (Year 9) we began to learn the irregular verbs and it was lists and lists and lists and cramming our heads. [C, 184-185]
As Rappaport (1981) points out, ignoring people's rights, in this case C's right to a varied programme, is the opposite of empowerment.

\section{Category 2. Surviving/Struggling (survival/difficulties)}

Being disempowered is enmeshed with struggle, another Marxist term. Y recounts his personal struggle during three years without a full-time teacher in collège:

It didn't take long to skew my English, you could say.

The time to get in a supply teacher, and it was never the same person. It was difficult for me. It was really difficult. [Y, 5-7]

This category captures the efforts made by the students to overcome obstacles or succumb to them. Surviving generally occurred out of school, whereas struggling occurred in school.

...it's true that it's not easy speaking English, but in the end, you always manage to make yourself understood. [B, 134-135]

$\mathrm{B}$ has been able to rise to the challenge of dealing with clients on a professional basis, even though he describes himself as demotivated in school.

\section{Category 3. Feeling comfortable/Feeling uncomfortable (comfort/discomfort)}

Bouchard and Berg (2017) associate feeling comfortable with a sense of belonging to a community: in a school this belonging may be in relation to a class, a subject, a teacher or peers.

I was happy. I was happy to do English. Yep. I was motivated. $[B, 3]$

B was comfortable doing English at primary school. He felt a sense of belonging, which is empowering.

I'm scared of having a mental block or starting and then having a mental block. It's hard when you see the others smiling, you know. [E, 188, 192]

$\mathrm{E}$ however is concerned about facing discomfort in front of the class. His sense of isolation indicates that he does not belong with the group at that moment. His peers are causing him to feel disempowered.

\section{Category 4. Showing self-awareness/Lacking self- awareness (level in English, successful strategies/desired level in English, unsuccessful strategies)}

For this category, self-awareness is defined as "knowing one's internal states, preferences, resources and intuitions" (Goleman, 1998, p.26). S has a clear sense of his strengths and weaknesses:

...I try to find the right words, and you know, sometimes I need a bit of time because I'm not as good in English as I'd like to be. [S, 249-251]

And yet he has also determined his capabilities according to preconceived views:

...I don't know. Spanish is easier to understand than English. Or at least, that's what we've been told. [S, 119-120] 
He is in effect disempowering himself by unquestioningly adopting the views of others.

\section{Category 5. Justifying motivation/Justifying demotivation (work, new, needing English, wanting to succeed/doing the basics, generalising about English, not wanting to succeed)}

In Sixième, things were OK, because, well, it was a new subject. [A, 60]

In this example, A was able to justify his positive motivation at the beginning of college, but the newness was not sufficient to maintain motivation afterwards.

It's an accent thing again, and I've heard that English people talk really quickly as well. [R, 200-202]

$\mathrm{R}$ is disempowering himself by placing too much emphasis on his accent and the fear that all English people speak quickly. He is justifying his demotivation.

\section{Category 6. Integrating with the other/Being isolated from the other (integration, travel, communication with English speakers/isolation)}

Gardner (1985) contends that the integrative motive is extremely important for achieving L2 proficiency because it leads to a positive attitude towards the L2 community. All twelve students have had enriching encounters with the L2 other at some point in their lives, for example, U went to China with the school:

We spent our afternoons with a Chinese class. We had to speak English to understand each other and we understood each other very well. We did the shops. We walked. It was cool. [U, 154-156]

But schools have also disempowered four of the students by depriving them of this possibility:

No, I've never had the chance to go away, go on a school trip, nothing at all. [O, 43]

\section{Core Category}

The six conceptual categories i.e. Being empowered/Being disempowered; Surviving/Struggling; Feeling comfortable/ Feeling uncomfortable; Showing self-awareness/Lacking self-awareness; Justifying motivation/Justifying demotivation; and Integrating with the other/Being isolated from the other, resemble an arena in which positive forces are propelling students towards learning achievements in English and negative forces are dragging them back. The core category that emerges is one of empowering versus disempowering forces. In Nicomachean Ethics, Aristotle (349B.C./1999) distinguishes between a compelling power from without and a power through choice from within. The compelling power can lead to feelings of pain or pleasure according to the level of coercion we are subjected to, whereas power through choice allows us to act or not act, either because we want what is good or we want to avoid what is bad. A compelling power therefore represents an external force, and power through choice represents an internal force. The dis/empowering forces in the core category are therefore external and internal; they dis/empower from within and from without.

\section{Force Field Analysis}

Lewin et al. (1939) used the notion of external/internal driving and restraining forces to resolve the following paradox: why should autocratic rather than laissez-faire leadership cause a group of boys to become aggressive or apathetic? In the case of an autocratic group leader, the findings indicated that a teenager may be driven towards aggressive behaviour in an attempt to break free from a rigid structure. On the other hand, friendships within the group may act as a restraining force. These factors, along with other interdependent cultural, sociological, psychological and physical factors, exist within a dynamic field that is the person and their environment (Lewin, 1939). The factors represent the total field and can be combined to explain the movement of behaviour in one direction or another at any given time (Lewin, 1943). To demonstrate his earlier findings on aggression among boys, Lewin (1947) produced a force field diagram. Changes to the amplitude of the forces in the field predict changes in behaviour (see Figure 5). Lewin also applied his research to factory productivity, which explains why his force field diagram has become a management tool. However, the modern version of this force field diagram has been simplified, ignoring the interdependency of numerous factors (Burnes \& Cooke, 2013).

Lewin's force field diagram encapsulates the arena of the core category: empowering (driving) forces propel students towards learning achievements in English whereas disempowering (restraining) forces drag them back. Research Question 1 on the causes of demotivation is answered by the core category: disempowering forces cause demotivation; empowering forces help students to overcome this demotivation. Furthermore, it is possible to design a simple measure of the students' current propensity to achieve according to the total number of theoretical codes that were derived from the student's transcript data. These theoretical codes can be assigned to each of the six conceptual categories of dis/empowering forces, giving a total for the individual category. The six categories can also be divided into two subsets, one representing Aristotle's internal forces (power from within) and the other, Aristotle's external forces (power from without). The final diagram provides a conceptual picture of the student's experiences, both positive and negative, of learning

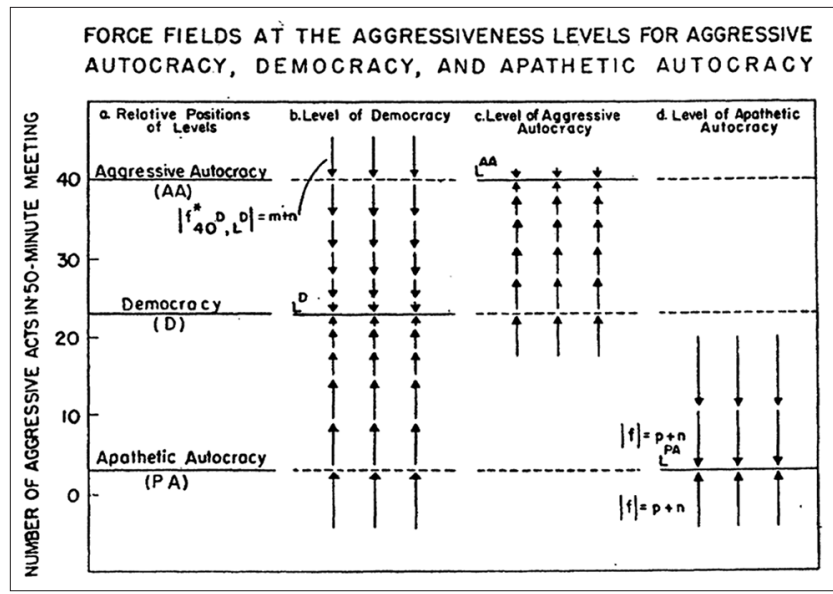

Figure 5. Lewin's force field diagram (1947, p.19) 
English in and out of school. Equilibrium represents neutrality: the student is neither prevented from making progress nor held back.

In Figure 6, the dis/empowering forces in N's learning environment may influence progress towards L2 proficiency. The only sizeable internal empowering force is 'showing self-awareness': $\mathrm{N}$ has a sense of her strengths and weaknesses. However, without individual support, which builds on her self-awareness and empowers her in other ways, numerous obstacles will continue to block her path to proficiency. Disempowering forces significantly outnumber empowering forces (29 to 13).

This contrasts with U's experiences (Figure 7), where a range of empowering 'out of school' forces have allowed him to overcome the disempowering 'in school' forces. He has been able to integrate with the English-speaking other and 'survived' these encounters. He also has a clear sense of how he can improve his English. The positive 'out of school' experiences should help him successfully move to- wards proficiency, but this will depend on further access to learning opportunities which are empowering.

Indeed, as the two cases highlight, a force field diagram may be used as both a tool to predict, and to empower, because its relative simplicity makes it accessible to all, thereby increasing student self-awareness on the path to L2 proficiency.

\section{Self-discrepancy Theory}

A force field diagram appears to capture the essence of the core category at one level, but it does not indicate all the repercussions of demotivation, such as emotional repercussions and how one person's dis/empowerment connects to another's (Research Question 2):

It didn't take long to feel disillusioned. Each of my English teachers, in Troisième (Year 10), Quatrième (Year 9) and Cinquième (Year 8), suffered from depression. [Y, 4-5]

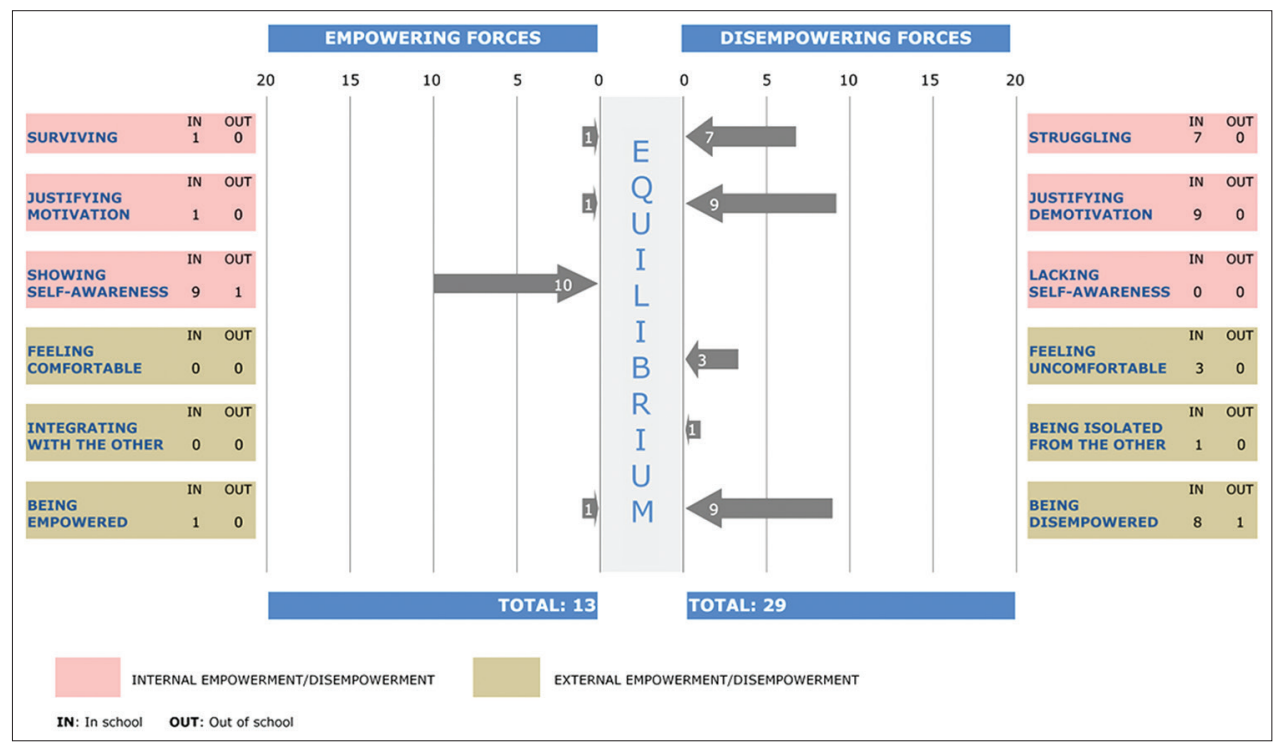

Figure 6. Force field diagram of progress towards L2 proficiency (participant N)

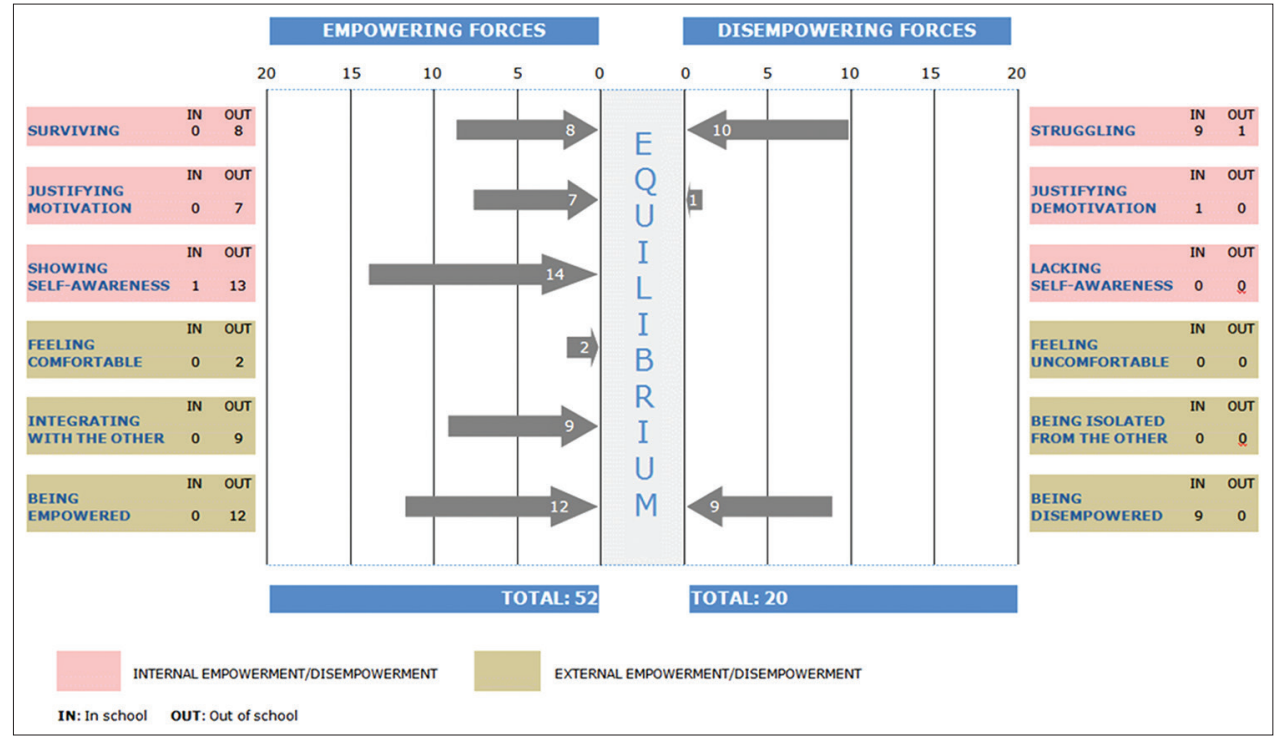

Figure 7. Force field diagram of progress towards L2 proficiency (participant U) 
For Y, and four other students, teacher absence became a disempowering force, but it must have been a disempowering force for the relevant teachers as well. One theory that seems to expand the scope of force field diagrams to encompass interdependent dis/empowerment factors is self-discrepancy theory.

The beginnings of a self-discrepancy theory are evident in the statement made by James (1890): "the emotion that beckons me on is indubitably the pursuit of an ideal social self, a self that is at least worthy of approving recognition by the highest possible judging companion" (p.315). An actual self is emotionally driven to become an ideal self under the appraising eye of others. Higgins (1987) presents six self-states (the six semicircles in Figure 8): the attributes of our actual, ought and ideal selves and others' perceptions of these attributes. Our own and other actual selves make up our self-concept; the four ought/ideal selves represent motivational self-guides. Self-discrepancy theory predicts the type of emotion a person will experience as a result of a discrepancy between the self-concept and the self-guides. This emotion depends on the magnitude, the accessibility, the context-relevance and the importance to the person of the

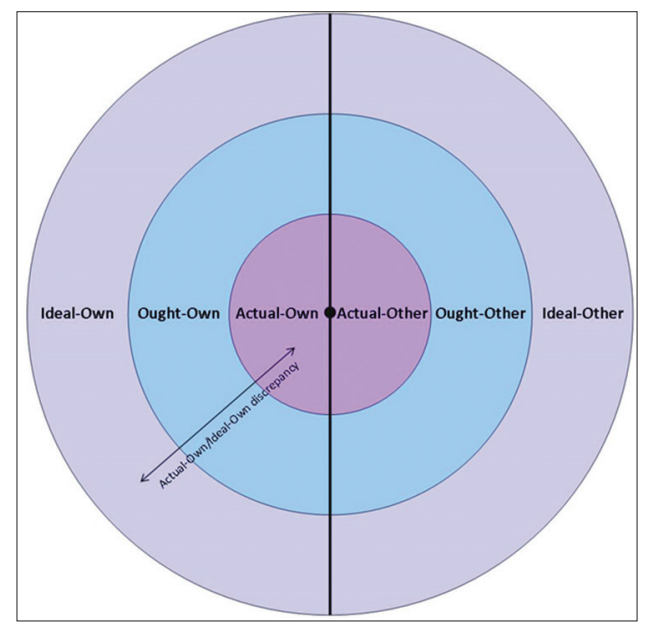

Figure 8. The six self-states with an example of the Actual-Own/Ideal-Own discrepancy discrepancy (Higgins, 1999); the radius of each concentric semicircle lengthens or shortens accordingly.

Discomfort occurs when the gap between self-concept and one of the self-guides grows too wide, for example, in N's case there is a discrepancy between her Actual-Own and Ideal-Own selves (see Figure 8): she wants to be able to readily communicate with clients, but feels incapable.

I can't. No, I don't know. I wouldn't be able to. [N, 83]

According to Higgins (1987), this should lead to feelings of dejection. There is also a discrepancy between her Actual-Own and Ought-Other selves: N's employer would expect her to be able to deal with clients, but again, she cannot, leading $\mathrm{N}$ to experience feelings of agitation. Negative emotions occur when the various selves are forced apart (disempowering) and positive emotions occur when they are forced together (empowering). Figure 9 is an approximate depiction of these influences on the students' selves over time and shifts the English learning process from the earlier descriptive depiction in Figure 4 to a conceptual depiction.

In Sixième, the Actual-Own and Ideal-Own selves are close together, causing feelings of cheerfulness and joy (Higgins \& Cornwell, 2016). This 'feeling comfortable' is confirmed by eight of the students. After Sixième the discrepancies between the student selves tend to increase as disempowering forces overwhelm empowering forces. On finishing Terminale at the age of 18, the gap between the Actual-Own and Ideal-Own student selves is particularly wide and may relate to the students acquiring an unrealistic ideal self (six students):

I have friends who've been on Erasmus, who've gone off for a year and come back completely bilingual. It's great. [T, 220-221]

$\mathrm{T}$ believes that he will become bilingual if he studies abroad for a year. On the Common European Framework of Reference for Languages (CEFRL), an L2 learner passes through six stages (A1 to $\mathrm{C} 2$ ) to reach the equivalent competences of a native speaker. $\mathrm{T}$ is constructing his ideal self as bilingual (C2) when at BTS level, students are expected to achieve B2 (DGES, 2008). B2 is the teacher's Ought-Other perception of T's ideal self. If a student's unrealistic

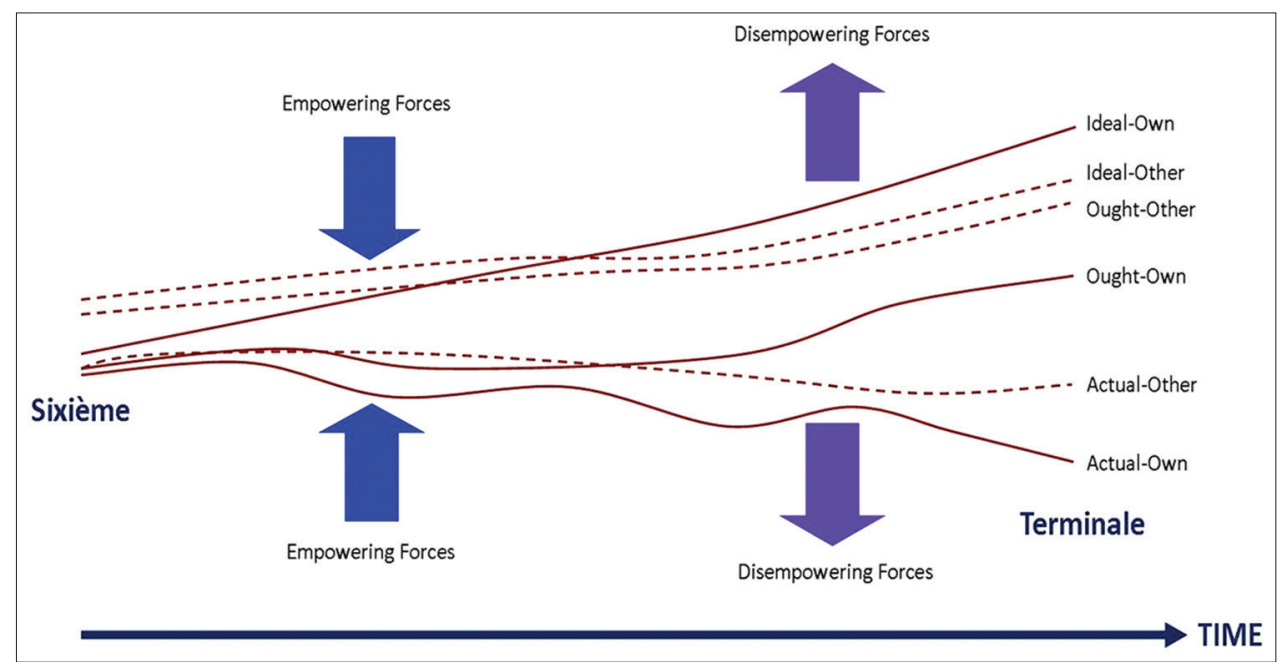

Figure 9. The students' actual/ought/ideal conceptual English language learning journey through school 
Ideal-Own self leads to dejection, the teacher's Ideal-Own self will tend to move away from his or her Actual-Own teaching self and also lead to dejection. The disempowering force on the teacher's selves may in turn be felt by the students.

\section{Force Field/Self-discrepancy Model}

It is clear that an integrated force field/self-discrepancy model offers an explanation for the causes of demotivation over time, the emotional repercussions from demotivation, and the influence of one person's demotivation on another's. We can imagine that each self is a metal strand inside a multiple conductor cable, the plastic coating is the learning environment, and an individual's self strands are intertwined with the self strands of other individuals (teachers, peers, etc.). Flowing through this cable is an emotional current generating electromagnetic dis/empowering forces that attract and repel the strands. The outer casing is flexible, expanding or contracting according to the extent of the context (class, school, work). An integrated model acknowledges the interdependency of numerous factors, but its very complexity may make it difficult to test quantitatively.

\section{DISCUSSION}

\section{The Motivational Self System}

One of the goals of the current research has been to step away from Dörnyei's Motivational Self System and examine demotivation from the L2 learner's point of view. In Dörnyei's model, which has been supported by a considerable amount of L2 research, the imagined future self i.e. the ideal self, is seen to be the key motivator. Dörnyei (2009) bases his assumption on the power of self-imagery, as epitomised by the world of professional athletes: having a clear vision and setting relevant objectives (the ought self). The twelve French students have a desired future self that will be capable of communicating fluently in both a professional and personal context, but this goal has been obstructed by disempowering forces which cause demotivation (Research Question 1). These forces comprise multiple variables that are not acknowledged in the learning environment component of the Dörnyei model. In addition, although the notion of ought/ideal selves derives directly from self-discrepancy theory, Dörnyei does not touch upon Higgins' belief that negative emotions are one of the repercussions of demotivation (Research Question 2).

Weiner (1985) saw a direct connection between a person's perceptions as to why they failed at a task and the impact of expectancy and emotion on their efforts to engage in similar future activities. The French students have constructed their 'in school' experience as a struggle: the term «c'est compliqué » (it's difficult) appears an astonishing 22 times in the transcripts. According to Weiner's theory, this constant struggle, with its accompanying negative emotions, should have caused the students to give up, but their desire to improve their English has held firm: their ideal L2 self continues to carry them forward. However, the actual L2 self is surviving rather than thriving, so the discrepancy between the ac- tual and ideal selves remains large. Perhaps this is because it requires a considerable investment to attain the ideal L2 self, so it is easier for the students to do other less important things as they wait for the right amount of time, energy and focus to do the important thing. This is a gumption trap (Pirsig, 1974): it stops a person reaching a state of Quality, in this case, L2 proficiency. We therefore have a situation where the ideal self is in fact a disempowering force, which contradicts Dörnyei's model and may partially explain France's ranking on the EPI. Indeed, bearing in mind the results of the current research, the Motivational Self System would benefit from further refinement, especially with regard to the emotional aspects of learning a second language, the impact of one person's motivation/emotion on another's and the multiplicity of the variables involved in the learning experience.

\section{Strengths and Limitations of the Project}

A major strength of this project is its originality. There is no evidence to suggest that a constructivist grounded theory approach has been used to explore demotivation among L2 learners. Another major strength is its empowering nature it has given a group of French student learners a voice, and the headteacher of the lycée is prepared to listen to this voice.

The theoretical codes from the grounded theory analysis were converted to numerical data to represent the magnitude of the forces involved in a student's force field diagram. However, as the original data was co-constructed, quantifying their properties shifts a socially constructed reality towards an actual reality, blurring the lines between constructivism and realism.

Charmaz (2014) advises the grounded theory researcher to stop gathering data when theoretical 'saturation' has been reached. This saturation assumes that the patterns in the codes no longer require new data to shape the properties of the conceptual categories: the link between the patterns and the properties is robust. The current research was conducted during a limited time frame with a limited number of participants and hence carried the risk that the data would not be sufficient to form a robust link. In the event, dis/empowerment became apparent at an early stage so that by the twelfth interview the properties of the conceptual categories were well-established. Nevertheless, one could argue that saturation failed to occur because the researchers were not in a position to adjust the interview questions and choose new interviewees, such as teachers, in the light of emerging concepts.

\section{Recommendations (Practice and Policy)}

It is recommended that schools promote dialogue between students and teachers over decisions that affect students (Ferguson et al., 2011). This should empower students to share their ideas for school improvement, such as the examples gleaned during the research project: protecting the new learner by speaking some French during English lessons in Sixième (Y), organising family exchange programmes (U), starting English at pre-school (A, S) and implementing peer support projects (L). These ideas are innovative, but without 
a formal system of feedback, they will not be heard.

The results tend to suggest that the journey towards English proficiency is beset with emotional highs and lows. Students would therefore benefit from access to counselling support, either from professionals, teachers or peers. This should from part of a school's behaviour policy.

It is interesting that none of the students referred to the levels from the Common European Framework of Reference for Languages (CEFRL) to describe their ability in English. 'Bilingual' as an ideal self is an unattainable goal for the majority of students, especially as it was reported that only $26 \%$ of French 16-year-olds had achieved A2 or above (Les Echos, 2012). Students should therefore be instructed in how to use the CEFRL as a self-assessment tool (its original purpose) to set realistic goals towards a realistic L2 future self.

\section{Future Research}

A qualitative research project is small-scale by nature, making it difficult to assert the applicability of an integrated force field/self-discrepancy model to other L2 learners without carrying out further research. One initial approach could be the preparation of a simple student questionnaire on dis/ empowerment. Results could then be plotted as a force field diagram for individual students. As a consequence, students would gain self-knowledge, which Higgins (1996) describes as a self-digest of knowledge that enables a person to optimise person-environment interaction through adaptation. Another possible avenue would be to expand the current project by interviewing L2 teachers on their experiences of dis/empowerment, and asking students questions that specifically deal with dis/empowerment in relation to emotion.

\section{CONCLUSION}

Despite similar levels of teaching and resources to other EU countries, France remains at the bottom of the English Proficiency Index. One obvious cause of this low ranking would appear to be demotivation, but a constructivist grounded theory approach using interview data from twelve French students shows that disempowering forces, such as feeling uncomfortable, struggling, and being isolated from the English-speaking other, create obstacles on the path to L2 proficiency, whereas empowering forces, such as justifying motivation and showing self-awareness, help the students overcome these obstacles. Indeed, if demotivation were the central cause of the low ranking, it would be a simple matter of replacing demotivating factors with motivating factors to improve the students' command of English. And yet even though all twelve students need English for the professional component of their sandwich course, overall progress has been limited, which would suggest that disempowering forces continue to outweigh empowering forces in the students' individual force fields. A failure to make progress also has emotional repercussions, and these emotions can be determined by combining force field analysis with the discrepancies between the students' actual/ought/ideal selves. This integrated force field/self-discrepancy model should enable us to understand why students struggle to achieve L2 proficiency and what feelings they undergo in the process. Further research is needed to test the validity, reliability and generalisability of the model, but until then it is vital that students are helped to set more realistic goals towards a more realistic ideal L2 self if they are to avoid this ideal L2 self transforming from an empowering force into a sense of disillusionment.

\section{REFERENCES}

Aristotle. (1999). Nicomachean Ethics. (W. D. Ross, Trans.). Kitchener: Batoche Books. (Original work published 349BC)

Arthur, S., \& Nazroo, J. (2003). Designing fieldwork strategies and materials. In Ritchie, J., \& Lewis, J. (Eds.), Qualitative Research Practice: A Guide for Social Science Students and Researchers (pp. 109-137). London: SAGE Publications.

Atkinson, J. W. (1957). Motivational determinants of risk-taking behavior. Psychological Review, 64(6), 359372. http://dx.doi.org/10.1037/h0043445

Bandura, A. (1977). Self-efficacy: Toward a unifying theory of behavioral change. Psychological Review, 84(2), 191215. http://dx.doi.org/10.1037/0033-295X.84.2.191

Berge, P. L., \& Luckmann, T. (1967). The Social Construction of Reality. New York: Anchor.

Blandford, A. (2013). Semi-structured qualitative studies. In Soegaard, M., \& Dam, R. F. (Eds.), The Encyclopedia of Human-Computer Interaction ( $2^{\text {nd }}$ ed.). Aarhus: The Interaction Design Foundation.

Bouchard, K. L., \& Berg, D. H. (2017). Students' school belonging: Juxtaposing the perspectives of teachers and students in the late elementary school years (Grades 4-8). School Community Journal, 27(1), 107-136. Retrieved from http://www.adi.org/journal/2017ss/BouchardBergSpring2017.pdf

Burnes, B., \& Cooke, B. (2013). Kurt Lewin's Field Theory: A Review and Re-evaluation. International Journal of Management Reviews, 15(4), 408-425. http://dx.doi. org/10.1111/j.1468-2370.2012.00348.x

Campbell, E. \& Storch, N. (2011). The changing face of motivation: A study of second language learners' motivation over time. Australian Review of Applied Linguistics, 34(2) 166-192. http://dx.doi.org/10.1075/aral.34.2. 03 cam

Charmaz, K. (2012). The power and potential of grounded theory. Medical Sociology Online, 6(3), 2-15. Retrieved from https://pdfs.semanticscholar.org/93d2/8c60474e31cedd4464c5b24ae0af2efbc090.pdf

Charmaz, K. (2014). Constructing Grounded Theory ( $2^{\text {nd }}$ ed.). London: SAGE Publications.

Charmaz, K. (2015). Teaching theory construction with initial grounded theory tools: A reflection on lessons and learning. Qualitative Health Research, 25(12), 16101622. http://dx.doi.org/10.1177/1049732315613982

Charmaz, K. (2017). The power of constructivist grounded theory for critical inquiry. Qualitative Inquiry, 23(1), 34-45. http://dx.doi.org/10.1177/1077800416657105

Charmaz, K., \& Henwood, K. (2007). Grounded Theo- 
ry. In Willig, C., \& Stainton-Rogers, W. (Eds.), The SAGE Handbook of Qualitative Research in Psychology (pp. 240-262). London: SAGE Publications.

Council of Europe. (2001) Common European Framework of References for Languages: Learning, teaching, assessment. Strasbourg: Language Policy Unit. Retrieved from https://www.coe.int/t/dg4/linguistic/source/framework_en.pdf

Deci, E. L., \& Ryan, R. M. (1985). The general causality orientations scale: Self-determination in personality. Journal of Research in Personality, 19(2), 109-134. http:// dx.doi.org/10.1016/0092-6566(85)90023-6

Direction Générale de l'Enseignement Supérieur. (2008) Programme et définition d'épreuve de langue vivante étrangère dans les brevets de technicien supérieur relevant du secteur industriel [Course of study and information vis-à-vis English language learning in an industry sector BTS]. Retrieved from https://www.sup.adc.education.fr/btslst/referentiel/prograLVE_BTS_STI.pdf

Dörnyei, Z. (2005). The Psychology of the Language Learner: Individual Differences in Second Language Acquisition. Mahwah: Lawrence Erlbaum.

Dörnyei, Z., \& Ushioda, E. (2011). Teaching and Researching: Motivation. (2 $2^{\text {nd }}$ ed.). Harlow: Pearson.

Dweck, C. S. (1986). Motivational processes affecting learning. American Psychologist, 41(10), 1040-1048. http:// dx.doi.org/10.1037/0003-066X.41.10.1040

Eccles, J., \& Wigfield, A. (1985). Teacher expectations and student motivation. In Dusek, J. B. (Ed.) Teacher Expectancies (pp. 185-226). London: Lawrence Erlbaum Associates.

Education First. (2016). EF English Proficiency Index. Lucerne: Education First Ltd. Retrieved from http://media2.ef.com/_/ /media/centralefcom/epi/downloads/ full-reports/v5/ef-epi-2015-english.pdf

Eggins, S. (2004). An Introduction to Systemic Functional Linguistics ( $2^{\text {nd }}$ ed.). London: Continuum International Publishing Group.

Ferguson, D. L., Hanreddy, A., \& Draxton, S. (2011). Giving students voice as a strategy for improving teacher practice. London Review of Education, 9(1), 55-70. http:// dx.doi.org/10.1080/14748460.2011.550435

Gardner, R. C. (1985). Social Psychology and Second Language Learning: The Role of Attitudes and Motivation. London: Edward Arnold.

Goleman, D. (1998). Working with Emotional Intelligence. New York: Bantam Books.

Higgins, E. T. (1987). Self-discrepancy: A theory relating self and affect. Psychological Review, 94(3), 319-340. http://dx.doi.org/10.1037/0033-295X.94.3.319

Higgins, E. T. (1996). The «self digest»: Self-knowledge serving self-regulatory functions. Journal of Personality and Social Psychology, 71(6), 1062-1083. http://dx.doi. org/10.1037/0022-3514.71.6.1062

Higgins, E. T. (1999). When do self-discrepancies have specific relations to emotions? The second-generation question of Tangney, Niedenthal, Covert, and Barlow (1998). Journal of Personality and Social Psychology, 77(6), 1313-1317. http://dx.doi.org/10.1037/0022-
3514.77.6.1313

Higgins, E. T., Bond, R. N., Klein, R., \& Strauman, T. (1986). Self-discrepancies and emotional vulnerability: How magnitude, accessibility, and type of discrepancy influence affect. Journal of Personality and Social Psychology, 51(1). 5-15. http://dx.doi.org/10.1037/0022-3514.51.1.5

Higgins, E. T., \& Cornwell, J. F. (2016). Securing foundations and advancing frontiers: Prevention and promotion effects on judgment \& decision making. Organizational Behavior and Human Decision Processes, 136, 56-67. http://dx.doi.org/10.1016/j.obhdp.2016.04.005

ICEF Monitor (2016). UK's English Language Teaching sector worth $£ 1.2$ billion. $15^{\text {th }}$ February. Retrieved from http://monitor.icef.com/2016/02/uks-english-languageteaching-sector-worth-1-2-billion/

James, W. (1890). The Principles of Psychology (Vol. 1). New York: Dover Publications.

Kim, T. Y., \& Kim, Y. K. (2014). A structural model for perceptual learning styles, the ideal L2 self, motivated behavior, and English proficiency. System, 46, 14-27. http://dx.doi.org/10.1016/j.system.2014.07.007

Kostoulas, A., \& Mercer, S. (2016). Fifteen years of research on self \& identity in System. System, 60, 128-134. http:// dx.doi.org/10.1016/j.system.2016.04.002

L. F. R. (2012, July 18). Le niveau en langues des élèves français pointé du doigt [French pupils' language ability takes the blame]. Les Echos. Retrieved from https://www.lesechos. fr/18/07/2012/LesEchos/21229-012-ECH_le-niveau-enlangues-des-eleves-francais-pointe-du-doigt.htm

Legard, R., Keegan, J., \& Ward, K. (2003). In-depth interviews. In Ritchie, J., \& Lewis, J. (Eds.) Qualitative Research Practice: A Guide for Social Science Students and Researchers (pp. 138-169). London: SAGE Publications.

Lewandowski, J-C. (2015, December 17). Les Français et la langue anglaise: de pire en pire... [French people and the English language: relations go from bad to worse]. Le Monde. Retrieved from http://focuscampus.blog. lemonde.fr/2015/12/07/les-francais-et-la-langue-anglaise-de-pire-en-pire

Lewin, K. (1939). Field theory and experiment in social psychology: Concepts and methods. American Journal of Sociology, 44(6), 868-896. http://dx.doi. org/10.1086/218177

Lewin, K. (1943). Defining the 'field at a given time'. Psychological Review, 50(3), 292-310. http://dx.doi. org/10.1037/h0062738

Lewin, K. (1947). Frontiers in group dynamics: Concept, method and reality in social science; social equilibria and social change. Human Relations, 1(1), 5-41. http:// dx.doi.org/10.1177/001872674700100103

Lewin, K., Lippitt, R., \& White, R. K. (1939). Patterns of aggressive behavior in experimentally created «social climates». The Journal of Social Psychology, 10(2), 269299. http://dx.doi.org/10.1080/00224545.1939.9713366

Lieb, K., von der Osten-Sacken, J., Stoffers-Winterling, J., Reiss, N., \& Barth, J. (2016). Conflicts of interest and spin in reviews of psychological therapies: A systematic review. BMJ Open, 6(4), 1-9. http://dx.doi.org/10.1136/ bmjopen-2015-010606 
Locke, K., Golden-Biddle, K. and Feldman, M. S. (2008). Making doubt generative: Rethinking the role of doubt in the research process. Organization Science, 19(6), 907-918. http://dx.doi.org/10.1287/orsc.1080.0398

Marx, K. (1887). Capital: A Critique of Political Economy (Vol. 1). (S. Moore, S. \& E. Aveling, Trans.). Moscow: Progress Publishers. (Original work published in 1867)

Pirsig, R. M. (1974). Zen and the Art of Motorcycle Maintenance. London: Corgi.

Popper, K. (1963). Conjectures and Refutations: The Growth of Scientific Knowledge. London: Routledge.

Poupore, G. (2013). Task motivation in process: A complex systems perspective. Canadian Modern Language Review, 69(1), 91-116. http://dx.doi.org/10.3138/cmlr.1139

Rappaport, J. (1981). In praise of paradox: A social policy of empowerment over prevention. American Journal of Community Psychology, 9(1), 1-25. http://dx.doi. org/10.1007/BF00896357

Sakai, H., \& Kikuchi, K. (2009). An analysis of demotivators in the EFL classroom. System, 37(1), 57-69. http:// dx.doi.org/10.1016/j.system.2008.09.005

Song, B., \& Kim, T. Y. (2017). The dynamics of demotivation and remotivation among Korean high school EFL stu- dents. System, 65, 90-103. http://dx.doi.org/10.1016/j. system.2016.12.010

The British Psychological Society. (2009). Code of Ethics and Conduct. Leicester: The British Psychological Society. Retrieved from https://beta.bps.org.uk/sites/beta. bps.org.uk/files/Policy\%20-\%20Files/Code\%20of\%20 Ethics\%20and\%20Conduct $\% 20 \% 282009 \% 29$.pdf

Tolman, E. C. (1938). The determiners of behavior at a choice point. Psychological Review, 45(1), 1-41. http:// dx.doi.org/10.1037/h0062733

Waninge, F., Dörnyei, Z., \& De Bot, K. (2014). Motivational dynamics in language learning: Change, stability, and context. The Modern Language Journal, 98(3), 704723. http://dx.doi.org/10.1111/modl.12118

Watters, A. (2015). The invented history of , the factory model of education: Retrieved from http://hackeducation. com/2015/04/25/factory-model

Weiner, B. (1985). An attributional theory of achievement motivation and emotion. Psychological Review, 92(4), 548-573. http://dx.doi.org/10.1037/0033-295X.92.4.548

Zimmerman, M. A. (2000). Empowerment theory. In Rappaport, J., \& Seidman, E. (Eds.) Handbook of Community psychology (pp. 43-63). New York: Springer. 